\title{
Helminthiasis saluran cerna pada sapi perah
}

\author{
Lili Zalizar \\ Program Studi Peternakan, Fakultas Pertanian dan Peternakan \\ Universitas Muhammadiyah Malang
}

Corresponden author: lilizalizarthahir@yahoo.com

\begin{abstract}
The purpose of this research was to find out prevalence and the rates of helminths infection and the kind of the helmints on dairy cows that was belonging KUBE Maju Mapan Cooperative in Jabung, Malang. A total of 123 dairy cows on farms was investigated for the possibility of a worm infection. Indications of worm infections was based on faecal worm egg discovery using floating method using saturated salt solution for nematode and cestode worms and sedimentation methods for the examination of worms trematodes. Examination of the number of worm's eggs use Whit lock chambers tool. Stool examination was done in the Laboratory of Animal Health belong to the Department of Animal Husbandry East Java Province in the district of Pakis Malang. The sample examination was done in 3 (three) times repetition.The results showed there are 2 (two) types of worm eggs, nematode type Strongyloid sp and Trematodes type Fasciola sp. The prevalence of Strongyloid infection in cattle is large enough that is equal to 33.33 percent (41 of 123 dairy cows). While the prevalence of the infected cattle Fasciola sp only 23.58 percent (29 of 123 dairy cows). The rate of infection or mean number of eggs per gram of feces of Strongyloid and Fasciola sp are only 2.43 and 1.88 per head of cattle. The efforts for worm medication regularly conducted by the Cooperative has been able to reduce the prevalence of the disease and the rates of infection.
\end{abstract}

Keywords : cooperative, cows, prevalence, worm infection

\section{PENDAHULUAN}

Kerugian akibat infeksi parasit khususnya cacing pada ternak di Indonesia sangat besar. Hal ini akibat cacing parasit menyerap zat-zat makanan, menghisap darah /cairan tubuh, atau makan jaringan tubuh ternak. Cacing parasit juga menyebabkan kerusakan pada sel-sel epitel usus sehingga dapat menurunkan kemampuan usus dalam proses pencernaan dan penyerapan zat-zat makanan serta produksi enzim-enzim yang berperanan dalam proses pencernaan. Selain itu berkumpulnya parasit dalam jumlah besar di usus atau lambung ternak dapat menyebabkan penyumbatan atau obstruksi sehingga proses pencernaan makanan terganggu.

Gangguan akibat cacing pada sapi perah dapat menyebabkan penurunan produksi susu pada ternak dewasa dan hambatan pertumbuhan pada ternak muda. Selain itu akibat infeksi cacing parasit menyebabkan kondisi tubuh ternak menurun sehingga dapat menggagalkan vaksinasi dan memungkinkan timbulnya berbagai penyakit lain seperti bakterial, viral maupun parasit lainnya.

Peternakan sapi perah umumnya tergabung dalam suatu koperasi. Perhatian dan pengetahuan koperasi 
terhadap penyakit cacing (helminthiasis) saluran cerna akan mempengaruhi tinggi rendahnya kasus infeksi cacing pada sapi perah di kelompok ternak di wilayah koperasi tersebut.

Penelitian ini dilakukan untuk mengetahui seberapa besar prevalensi dan derajat infeksi cacing yang menyerang di peternakan sapi perah yang tergabung dalam Koperasi Usaha Bersama (KUBE) Maju Mapan di Kecamatan Jabung.

\section{MATERI DAN METODE}

Sebanyak 123 ekor sapi perah di peternakan yang tergabung di Koperasi KUBE di Jabung Kabupaten Malang diteliti terhadap kemungkinan adanya infeksi cacing. Indikasi adanya infeksi cacing berdasarkan ditemukannya telur cacing pada feses dengan memakai metode apung untuk cacing nematoda dan cestoda dengan menggunakan larutan garam jenuh dan metode sedimentasi untuk pemeriksaan cacing trematoda. Pemeriksaan jumlah telur cacing memakai alat hitung Whitlock.Pemeriksaan feses dilakukan di Laboratorium UPT Kesehatan Hewan milik Dinas Peternakan Propinsi Jawa Timur di Kecamatan Pakis Malang.Pemeriksaan sampel dilakukan 3 (tiga) kali ulangan. Variabel yang diamati dalam penelitian ini adalah prevalensi infeksi cacing dan derajat infeksi (dilihat dari jumlah telur cacing tiap gram tinja/TTGT). Metode penelitian ini menggunakan survei dengan porposive sampling dengan kriteria sapi yang diambil sampel fesesnya adalah sapi betina laktasi 2. Ulangan pengamatan sampel 3 (tiga) kali.

\section{HASIL DAN PEMBAHASAN}

Menurut Ronohardjo \& Nari (1977), mengingat kondisi lingkungan Indonesia menguntungkan bagi parasit maka peternakan di Indonesia tidak dapat membebaskan diri dari infeksi mahluk tersebut. Satrija et al. (2003, berpendapat bahwa iklim tropis di Indonesia yang hangat dan basah memberikan kondisi yang menguntungkan bagi perkembangan telur dan ketahanan hidup larva dan telur infektif cacing di alam. Faktor cuaca di Kabupaten Malang cukup mendukung hidup cacing. Kabupaten Malang memiliki suhu berkisar antara $21-29^{\circ} \mathrm{C}$ dengan kelembaban antara 60-90 persen. Kondisi tersebut cocok dengan kebutuhan hidup telur cacing dan larva di lingkungan.

Pada Tabel 1 hasil pemeriksaan terhadap feses memperlihatkan sapi perah terinfeksi 2 jenis cacing yaitu cacing jenis nematoda (cacing gilig) dan trematoda (cacing pipih). Kedua jenis cacing ini termasuk yang cukup sering ditemukan pada sapi baik sapi perah maupun sapi potong. Hal tersebut sama dengan hasil penelitian Erwin, Kamal dan Rusdiana (2010) di Rumah Potong Hewan (RPH) di Palembang menunjukkan bahwa pengamatan pada 96 sampel feses sapi, didapatkan telur cacing hanya yang berasal dari dua kelompok cacing parasit tersebut. Penelitian Tantri dkk (2013) di RPH Kota Pontianak Kalimantan Barat menunjukkan bahwa infeksi nematoda dan trematoda lebih tinggi daripada cestoda.

Tabel 1 memperlihatkan sapi perah terinfeksi cacing parasit anggota ordo Strongyloid dari superfamili Trichostrongyloidea. Cacing tersebut merupakan parasit paling penting pada sapi, domba dan ruminansia lainnya. Cacing dewasa anggota Trichostrongyloidea mengeluarkan telur yang disebut "telur tipe Strongyloid" yaitu telur dengan membran luar yang tipis dan hanya beberapa saja sel nya yang telah mengalami pembelahan sebelum dikeluarkan dari tubuh, oleh karena itu disebut cacing Strongyloid (Noble et al, 1989). 
Anggota dari cacing dengan telur jenis Strongyloid tersebut ini cukup banyak. Cacing Haemonchus $s p$,Cooperia sp,Trichostrongylus $s p$ dan Ostertagia ostertagi merupakan contoh dari jenis cacing tersebut dengan dan dapat menyebabkan produktivitas ternak menurun sehingga merugikan secara ekonomi (Soulsby,1982).

Rata-rata prevalensi ternak yang terserang infeksi Strongyloid cukup besar yaitu sebesar 33,33 persen (41 dari 123 ekor). Siklus hidup cacing jenis ini yang langsung dan tidak memerlukan inang antara mempermudah keberlangsungan parasit tersebut di alam. Setelah telur cacing dikeluarkan dari rektum bersama dengan feses maka telur akan berkembang menjadi larva di lingkungan. Setelah mencapai stadium larva infektif, apabila larva tersebut termakan karena menempel di rumput maka larva infektif akan menetas di saluran cerna dan berkembang menjadi cacing dewasa di dalam tubuh ternak sapi.
Prevalensi ternak yang terserang infeksi Fasciola sp hanya 23,58 persen, lebih kecil daripada Strongyloid. Hal ini kemungkinan besar karena siklus hidup cacing Fasciola sp lebih rumit daripada Strongyloid. Cacing Fasciola sp memerlukan inang antara berupa siput. Telur cacing tersebut keluar bersama feses dan dari telur yang menetas keluar mirasidium yang akan masuk ke dalam tubuh siput.Mirasidium di dalam tubuh siput berkembang menjadi sporokista; sporokista akan menghasilkan redia dan redia akan berkembang dan menghasilkan serkaria. Serkaria akan keluar dari siput dan merupakan fase infektif. Apabila tidak segera termakan oleh sapi, maka serkaria akan mengkista dan menempel pada rumput/tanaman air. Infeksi terjadi pada waktu ternak minum air yang mengandung metaserkaria atau memakan rumput/tanaman air yang mengandung metaserkaria (Kusumamihardja, 1992).

Tabel 1. Prevalensi (\%) dan rataan jumlah telur cacing pada sapi perah*

\begin{tabular}{cccccc}
\hline $\begin{array}{c}\text { Jenis Telur } \\
\text { (Kelas) }\end{array}$ & $\begin{array}{c}\text { Jumlah } \\
\text { Sampel (n) } \\
\text { (ekor) }\end{array}$ & Ulangan & $\begin{array}{c}\text { Jumlah Sapi } \\
\text { yang } \\
\text { Terinfeksi } \\
\text { (ekor) }\end{array}$ & $\begin{array}{c}\text { Prevalensi } \\
(\%)\end{array}$ & $\begin{array}{c}\text { Rataan Jumlah } \\
\text { Telur Cacing } \\
\text { (butir/gr feses) }\end{array}$ \\
\hline trongyloid & \multirow{2}{*}{123} & 1 & 40 & 32,52 & 2,98 \\
(Nematoda) & 2 & 43 & 34,96 & 2,32 \\
\hline Rataan & & 3 & 40 & 32,52 & 1,98 \\
\hline Fasciola sp & \multirow{2}{*}{123} & 1 & 41 & 33,33 & 2,43 \\
(Trematoda) & 2 & 29 & 26,01 & 3 \\
\hline Rataan & & 3 & 26 & 23,58 & 1,63 \\
\hline
\end{tabular}

* Data diolah

Prevalensi ternak yang terserang Fasciola sp pada penelitian ini lebih rendah dari prevalensi infeksi cacing tersebut pada ternak sapi potong yang disembelih di RPH Samarinda yang mencapai 44,44\% (Jusmaldi dan Saputra,
2009). Purwanta et al (2006), juga melaporkan prevalensi Fasciola sp cukup tinggi yaitu mencapai 53,95\% (41 dari 76 ekor) pada sapi Bali. Demikian juga menurut Molloy et al (2005), prevalensi ternak yang terserang Fasciola $s p$ pada 
sapi potong di Australia mencapai 52,2\%. Perbedaan tersebut bisa disebabkan karena adanya perbedaan kekebalan terhadap infeksi cacing tersebut, adanya kebiasaan sapi potong digembalakan dan adanya perbedaan bangsa atau jenis ternak (Tasawar et al. 2007). Selain itu daerah dataran rendah dengan banyak wilayah yang sering tergenang air dan ditemukan siput yang merupakan sebagai inang antara Fasciola sp memberi peluang yang lebih besar untuk terjadinya infeksi cacing tersebut. Faktor lain pada kebiasaan peternak yang memberikan rumput yang masih basah di pagi hari tanpa dilayukan terlebih dahulu mempertinggi kemungkinan terjadinya infeksi cacing.

Derajat infeksi atau rataan jumlah telur cacing per gram feses termasuk rendah. Rataan jumlah telur cacing per gram tinja untuk cacing Strongyloid hanya 2,43 per ekor ternak. Hal ini karena Koperasi (KUBE) Maju Mapan Kecamatan Jabung Kabupaten Malang rutin memberikan obat cacing setiap 3-6 bulan sekali dengan jenis obat cacing (antelmintik) yang mengandung piperazin. Piperazin merupakan obat yang efektif untuk cacing Nematoda termasuk kelompok Strongyloid. Piperazin menyebabkan kelumpuhan otot cacing sehingga cacing mudah dikeluarkan oleh gerakan peristaltik usus (Bjørn, 1992).

Walaupun upaya Koperasi tersebut sudah efektif dalam menurunkan derajat infeksi cacing, namun dalam pemakaian antelmintik sebaiknya tidak terus menerus menggunakan jenis obat yang sama karena akan merangsang terjadinya resistensi. Menurut Bjørn (1992) dan Ridwan et al (2000), frekuensi pemberian antelmintik dengan jenis yang sama dalam jangka lama dapat menyebabkan terjadinya resistensi cacing terhadap antelmintik tersebut. Demikian juga hasil penelitian Zalizar (2009) dan
Zalizar dan Satrija (2009), pada ternak lain (ayam petelur) memperlihatkan bahwa efikasi piperazin dan albendazole hanya mencapai 69 persen (tidak efektif) dan 76 persen (kurang efektif). Tidak tertutup kemungkinan bahwa suatu saat pada sapi perah di Indonesia juga dapat terjadi resistensi cacing terhadap antelmintik yang diberikan, mengingat pola pemberian obat dengan jenis yang sama dalam jangka lama. Oleh karena itu diperlukan metode lain dalam upaya pengendalian penyakit kecacingan pada ternak selain antelmintik.

Menurut da Silva et al (2012), untuk menangulangi infeksi cacing pada ternak yang digembalakan sebaiknya dilakukan rotasi padang penggembalaan dan pemberian suplementasi nutrisi. Peternakan sapi perah di Indonesia umumnya dikandangkan tidak digembalakan, upaya pencegahan penyakit cacing dapat dilakukan dengan memberikan rumput yang dipotong pada siang hari, karena apabila dipotong pada pagi hari larva cacing masih berada di bagian atas (pucuk) rumput sehingga pada waktu rumput disabit larva tersebut dapat terbawa ke kandang dan termakan oleh sapi.Selain itu menjaga sanitasi kandang agar selalu dalam keadaan bersih diharapkan dapat mengurangi infeksi cacing.

Menurut Vercruysse et al. (2002), penggunaan antelmintik sebaiknya menggunakan obat yang mempunyai efikasi 90 persen atau lebih. Pemakaian antelmintik yang mempunyai efikasi yang rendah dapat memicu terjadinya resistensi.Adanya kemungkinan telah terjadi resistensi tersebut sangat merugikan peternak karena berarti obat yang diberikan kurang efektif lagi dalam mengendalikan penyakit sehingga produktivitas ternak tetap rendah dan incomenya menurun. 
Tabel 2. Prevalensi infeksi telur cacing tunggal dan campuran

\begin{tabular}{lccc}
\hline Infeksi Tunggal / Campuran & $\begin{array}{c}\text { Sample Sapi (n) } \\
(\text { ekor) }\end{array}$ & $\begin{array}{c}\text { Rataan Sapi } \\
\text { Terinfeksi (ekor) }\end{array}$ & $\begin{array}{c}\text { Prevalensi } \\
(\%)\end{array}$ \\
\hline Tunggal (Strongyloid atau & & 68 & 55,28 \\
Fasciola saja) & & & \\
Campuran (Strongyloid + & $\mathrm{n}=123$ & 2 & 1,63 \\
Fasciola) & & 53 & 43,09 \\
Tidak Terinfeksi & & 123 & 100 \\
\hline Jumlah & &
\end{tabular}

Antelmintik piperazin tidak efektif untuk cacing Trematoda seperti Fasciola sp. Koperasi KUBE Maju Mapan memberikan antelmintik piperazin sehingga tidak dapat membunuh cacing Fasciola sp. Namun prevalensi dan derajat infeksi cacing tersebut lebih rendah dari cacing jenis Stronyloid. Hal ini terutama akibat untuk melengkapi siklus hidupnya, cacing Fasciola memerlukan inang antara berupa siput. Sedangkan siput tersebut umumnya hanya ditemukan ditemukan di lahan yang ada airnya misalnya di sawah atau di padang rumput dekat sungai/kali yang sering banjir. Wilayah Kabupaten Malang dengan dataran tinggi dan tempat menanam rumput yang umumnya jauh dari selokan/sungai mengurangi peluang mirasidium untuk bertemu dengan siput. Hal tersebut menyebabkan infeksi Fasciolosis di Kabupaten Malang lebih sedikit daripada Strongyloidosis. Pada Tabel 2, terlihat bahwa jumlah ternak yang terinfeksi dengan telur cacing tunggal (Strongyloid atau Fasciola saja) lebih banyak daripada infeksi campuran. Hal itu menunjukkan bahwa infeksi campuran antara cacing jenis Strongyloid dan Fasciola sp lebih sulit terjadi, kemungkinan besar akibat siklus hidup Fasciola sp yang lebih kompleks.

\section{KESIMPULAN}

Peternakan sapi perah anggota Koperasi (KUBE) Maju Mapan di Kecamatan Jabung Kabupaten Malang terinfeksi cacing jenis Strongyloid dan Fasciola $s p$ dengan prevalensi dan derajat infeksi yang ringan. Upaya pengobatan yang rutin diberikan oleh Koperasi telah mampu menurunkan prevalensi ternak yang terserang dan derajat infeksi cacing.

Diharapkan tidak menggunakan jenis obat cacing yang sama terus menerus dalam jangka yang lama untuk mencegah terjadinya resistensi.

\section{UCAPAN TERIMA KASIH}

Terima kasih yang sebesarbesarnya disampaikan kepada Universitas Muhammadiyah Malang atas dana kompetitif Blockgrant Penelitian yang diberikan untuk membiayai penelitian ini.

\section{DAFTAR PUSTAKA}

Da Silva, B. J.,CP Rangel, AH da Fonseca and JPG Soares.2012. Gastrointestinal Helminths in Calves and Cows in Organic Milk Production System. Rev.Bras. Parasitol.Vet., Jaboticabal.Vol 2 (2):87-91

Erwin N., Kamal M, dan Rusdiana A.,2010. Identitas Jenis Telur Cacing Parasit Usus Pada Ternak Sapi (Bos sp.) dan 
Kerbau (Busbalus sp.) di Rumah Potong Hewan Palembang. Jurnal Penelitian. Universitas Sriwijaya. Sumatra Utara. Hal 06-11

Jusmaldi dan Saputra, Y. 2009. Prevalensi Infeksi Cacing Hati (Fasciola hepatica) pada Sapi Potong di Rumah Potong Hewan Samarinda. Jurusan Biologi FMIPA Universitas Mulawarman. Bioprospek. Vol. 6 (2): 55-61

Kusumamihardja S.1992. Parasit dan Parasitosis pada Hewan Ternak dan Hewan Piaraan di Indonesia. Bogor: Pusat Antar Universitas Bioteknologi Institut Pertanian Bogor.

Molloy, J. B.,G.R. Anderson, T.I. Flether, J. Landmann and B.C.Knight. 2005. Evaluation of a commercially available enzym-linked immunosorbent assay for detecting antibodies to Fasciola hepatica and Fasciola gogantica in cattle, sheep and buffaloes in Australia. Vet.Parasitol., 130:207-212

Noble ER., GA Noble., GA Schad, AJ MacInnes. 1989. Parasitology, The Biology of Animal Parasites.

$6^{\text {th }}$ Edition.Philadelphia: Lea \& Febiger.574pp.

Purwanta,Ismaya NRP dan Burhan.2006. Penyakit Cacing Hati (Fasciolosis) pada Sapi Bali di Perusahaan Daerah Rumah Potong Hewan (RPH) Kota Makasar. Jurnal Agrisistem Vol 5 (1): 10-21

Ridwan Y., Satrija F, Novianti E, Retnani EB, Tiuria R. 2000. Resistensi Haemonchus contortus terhadap Albendazol pada Peternakan Domba di Bogor. Prosiding International
Seminar of Soil Transmitted Helminth dan Seminar Nasional Perkumpulan Pemberantasan Penyakit Parasitik Indonesia, Bali 21-24 Februari 2000.

Ronohardjo P, Nari J. 1977. Beberapa Masalah Penyakit Unggas di Indonesia. Di dalam: Ilmu dan Industri Perunggasan. Seminar Pertama, 30-31 Mei 1977, Cisarua, Bogor, Indonesia. Pusat Penelitian dan Pengembangan Peternakan. hlm 1-15.

Satrija F, Ridwan Y, Retnani EB. 2003. Perbandingan Efikasi Berbagai Bentuk Sediaan Obat Cacing Albendazol terhadap Cacing Haemonchus Contortus dan Trichostrongylus spp pada Domba. Makalah Seminar Strategi Pemanfaatan Antelmintik untuk Pengendalian Kecacingan pada Ternak, 11 Februari 2003. Bogor.

Soulsby, EJL. 1982. Helminths, Arthropods and Protozoa of Domesticated Animals. $7^{\text {th }}$ Ed. Philadelpia: Lea and Febiger.

Tantri N,Tri Rima S dan Siti Khotimah. 2013. Prevalensi dan Intensitas Telur Cacing Parasit Pada Feses Sapi (Bos sp) di Rumah Potong Hewan (RPH) kota Pontianak kalimantan Barat. Jurnal Protobiont Vol 2 (2): 102-106

Tasawar Z., U. Minir, C.S. Hayat and M.H. Lashari. 2007. The Prevalence of Fasciola hepatica in Goats Around Multan. Pakistan Vet. J.27(1): 5-7

Vercruysse J, Holdsworth P, Letonja T, Conder G, Hamamoto K, Okano K, Rehbein. 2000. International Harmonisation of Anthelmintic Efficacy guideline (Part2). Veterinary Parasitology 103: 277-297 
Zalizar L, Fadjar Satrija. 2009. Dampak perbedaan Dosis Infeksi Ascaridia galli dan Pemberian Piperazine terhadap Jumlah Cacing dan Berat Badan Ayam Petelur. Animal Production. Jurnal Produksi Ternak (terakreditasi) 11(3):176182

Zalizar. L. 2009. Dampak Perbedaan Dosis Infeksi Ascaridia galli Dan Pemberian Albendazol terhadap Jumlah Cacing Dan Bobot Hidup Ayam Petelur. Jurnal Saintek 6(1):29-33.ISSN No 1693-8917 